\title{
PENINGKATAN KETERAMPILAN PROSES PEMECAHAN MASALAH DAN HASIL BELAJAR MATEMATIKA MENGGUNAKAN MODEL $P B L$ TERINTEGRASI PENILAIAN AUTENTIK PADA SISWA KELAS VI SDN 2 BENGLE, WONOSEGORO
}

\author{
Sri Giarti \\ sgiarty@gmail.com \\ SD Negeri Bengle 2, Wonosegoro, Boyolali
}

\begin{abstract}
ABSTRAK
Tujuan penelitian ini adalah untuk meningkatkan keterampilan proses pemecahan masalah, hasil belajar Matematika siswa kelas VI SD Negeri 2 Bengle menggunakan model pembelajaran Problem Based Learning (PBL) terintegrasi penilaian autentik. Jenis penelitian yang digunakan dalam penelitian ini adalah penelitian tindakan kelas, yang terdiri dari dua siklus. Masing-masing siklus terdiri atas tahapan perencanaan tindakan, pelaksanaan tindakan, observasi, dan refleksi. Instrumen pengumpulan data menggunakan rubrik penilaian keterampilan proses pemecahan masalah, dan soal tes Matematika materi Debit air. Analisis data dilakukan dengan menggunakan analisis deskriptif komparatif yaitu membandingkan kondisi awal sebelum dilakukan tindakan, hasil siklus 1, dan siklus 2. Hasil penelitian menunjukkan temuan bahwa model PBL terintegrasi penilaian autentik dapat: a) meningkakan keterampilan proses pemecahan masalah matematika siswa kelas VI SD Negeri 2 Bengle, Wonosegoro - Boyolali. Persentase kenaikan keterampilan pemecahan masalah matematika sebesar $28,54 \%$ untuk siklus 1 dan 35,46 $\%$ untuk siklus 2. b) Meningkatkan persentase jumlah siswa yang mencapai ketuntasan belajar minimal (KKM) berikut: pada kondisi awal, persentase pencapaian KKM sebesar $30,77 \%$ (4 siswa), pada siklus 1 persentase meningkat menjadi 53,84\% ( 7 siswa), dan pada siklus 2 persentase jumlah siswa yang mencapai KKM meningkat menjadi 84,61\% (11 siswa).

Kata kunci: keterampilan proses pemecahan masalah, hasil belajar, model pembelajaran $P B L$, penilaian autentik

\section{PENDAHULUAN}

Matematika merupakan salah satu matapelajaran bidang ke-SD-an yang menjadi muatan utama dalam kurikulum SD/MI Tahun 2006. Namun, pandangan siswa terhadap pelajaran matematika secara umum kurang terta-

rik. Matematika dianggap sebagai pelajaran yang sulit sehingga kurang diminati. Lampiran Permendiknas nomor 22 tahun 2006 tentang standar isi mata pelajaran matematika SD/MI menjelaskan bahwa pembelajaran Matematika diberikan untuk membekali peserta didik untuk berpikir logis, ana-
\end{abstract}


litis, sistematis, kritis dan kreatif serta kemampuan kerja sama dikutip dari (Depdiknas, 2006). Sehingga peserta didik mampu memperoleh, mengelola, dan memanfaatkan informasi untuk bertahan hidup pada keadaan yang selalu berubah, tidak pasti dan kompetitif. Dari penjelasan tersebut jelaslah bahwa karakteristik matematika yang memiliki objek kajian abstrak, berkaitan dengan karakteristik siswa SD yaitu senang merasakan atau melakukan/memperagakan sesuatu secara langsung.

Kenyataannya tujuan matematika agar siswa mampu berpikir logis, analitis, sistematis, kritis dan kreatif serta kemampuan kerja sama masih jauh dari harapan. Hasil observasi peneliti dan teman sejawat pada pembelajaran di kelas 6 SD N 2 Bengle menemukan permasalahan bahwa pembelajaran matematika masih berpusat pada guru. Guru masih menggunakan metode konvensional, dimana guru hanya memberikan ceramah, pemberian contoh, dan pemberian tugas. Sehingga siswa kurang terlibat dalam proses pembelajaran, cenderung pasif, hanya mendengarkan penjelasan guru dan mengerjakan soal-soal tanpa ada kegiatan yang melibatkan siswa secara langsung.

Kondisi pembelajaran Matematika yang pasif dan hanya mendengarkan tersebut berdampak pada rendahnya keterampilan proses pemecahan masalah matematika dan hasil belajarnya.
Pada pembelajaran pokok bahasan menyelesaikan masalah penggunaan akar dan pangkat, hanya 4 siswa $(30,77 \%)$ menunjukkan keterampilan proses pemecahan masalah matematika pada kategori tinggi, 65 siswa $(38,46 \%)$ pada kategori sedang, dan 4 siswa $(30,77 \%)$ pada kategori rendah.

Rendahnya keterampilan proses pemecahan masalah matematika ini berdampak pada hasil belajar siswa. Data awal tingkat kompetensi hasil belajar siswa dengan KKM 60 ternyata hanya ada 3 siswa $(30,77 \%)$ yang telah mencapai KKM dan rerata skornya berada pada kategori tinggi. Sedangkan 9 siswa $(69,23 \%)$ belum mencapai KKM, dengan rincian 5 siswa $(38,46 \%)$ pada rerata skor kategori sedang dan 4 siswa $(30,77 \%)$ pada rerata skor kate- gori rendah.

Dari hasil studi pendahuluan tentang keterampilan proses pemecahan masalah matematika dan hasil belajar siswa, dapat disimpulkan bahwa masih terjadi kesenjangan yang cukup tinggi dalam hal keterampilan pemecahan masalah matematika dan hasil belajar siswa. Besarnya kesenjangan pencapaian hasil belajar siswa yang telah mencapai KKM sebesar 69,23\%. Melihat kondisi seperti ini, peneliti berupaya melakukan perbaikan pembelajaran dalam rangka meningkatkan keterampilan proses pemecahan masalah matematika dan hasil belajarnya. Kajian pustaka yang dilakukan peneliti menemukan informasi berbagai model 
yang sangat potensial untuk meningkatkan keterampilan proses pemecahan masalah matematika dan hasil belajar siswa

Slameto (2011: 7) menyebutkan model pembelajaran inovatif diantaranya; Cooperative Learning, Contextual Teaching and Learning, Realistik Mathematics Education, Problem Based Learning, Problem Promting, Cycle Learning, Examples and NonExamples. Dari berbagai model pembelajaran yang ada, model $P B L$ merupakan model pembelajaran yang sangat potensial untuk meningkatkan hasil belajar dan meningkatkan keterampilan proses pemecahan masalah matematika. Potensi $P B L$ tersebut oleh karena sintak pembelajarnnya relevan dengan keterampilan proses pemecahan masalah matematika.

Berdasarkan latar belakang seperti tersebut di atas, permasalahan penelitian yang akan dipecahkan dalam PTK ini adalah apakah model pembelajaran $P B L$ terintegrasi penilaian autentik dapat meningkakan keterampilan proses pemecahan masalah Matematika dan seberapa tinggi peningkatan keterampilan proses pemecahan masalah matematika dan hasil belajar siswa tersebut bisa tercapai.

\section{KAJIAN PUSTAKA}

\section{Hakikat Matematika dan Pembela- jaran Matematika}

Depdiknas (2006) menjelaskan bahwa hakikat matematika merupakan "bahan kajian yang memiliki konsep abstrak dan dibangun melalui konsep penalaran deduktif, yaitu kebenaran suatu konsep diperoleh sebagai akibat logis dari kebenaran sebelumnya sudah diterima sehingga keterkaitan antara konsep dalam matematika sangat luas dan jelas".

Menurut Wahyudi (2012:10), "matematika berkenaan dengan ide (gagasan-gagasan), aturan-aturan, hubungan-hubungan, yang diatur secara logis sehingga matematika berkaitan dengan konsep-konsep abstrak. Matematika merupakan pengetahuan yang disusun secara deduktif dan dapat digunakan untuk mendidik dan melatih untuk berpikir secara logik". Sejalan dengan Wahyudi, Heruman (2007:27) mengemukakan "matematika merupakan ilmu pengetahuan yang mempelajari struktur yang abstrak dan pola hubungan yang ada didalamnya". Hal ini berarti belajar matematika pada hakekatnya adalah belajar konsep, struktur konsep dan mencari hubungan antar konsep dan strukturnya.

Berdasarkan beberapa pendapat yang telah dikemukakan, penulis menyimpulkan bahwa matematika merupakan suatu pelajaran yang tersusun secara beraturan, logis, berjenjang dari yang paling mudah hingga ke paling rumit. Sedangkan pembelajaran matematika pada hakikatnya adalah proses yang sengaja dirancang dengan tujuan untuk menciptakan suasana lingkungan memungkinkan seseorang (siswa) melaksanakan kegiatan belajar matemati- 
Peningkatan Keterampilan Proses Pemecahan Masalah Dan Hasil Belajar Matematika Menggunakan Model PBL (Sri Giarti)

ka, dan proses tersebut berpusat pada guru mengajar matematika. Pembelajaran matematika seharusnya mampu menanamkan konsep matematika secara jelas, tepat dan akurat kepada siswa sesuai dengan jenjang kelasnya.

Tentang hakikat Matematika ini, lebih lanjut lampiran Permendiknas No. 22 Tahun 2006, menjelaskan bahwa Matematika merupakan ilmu universal yang mendasari perkembangan tekno- logi modern, mempunyai peran penting dalam berbagai disiplin dan mema- jukan daya pikir manusia (Depdiknas, 2006). Perkembangan pesat teknologi informasi dan komunikasi dewasa ini dilandasi oleh perkembangan matematika di bidang teori bilangan, aljabar, analisis, teori peluang dan matematika diskrit. Untuk menguasai dan mencipta teknologi di masa depan diperlukan penguasaan matematika yang kuat sejak dini. Mata pelajaran Matematika perlu diberikan kepada semua peserta didik mulai dari sekolah dasar untuk membekali peserta didik dengan kemampuan berpikir logis, analitis, sistematis, kritis, dan kreatif, serta kemampuan bekerjasama. Kompetensi tersebut diperlukan agar peserta didik dapat memiliki kemampuan memperoleh, mengelola, dan memanfaatkan informasi untuk bertahan hidup pada keadaan yang selalu berubah, tidak pasti, dan kompetitif. Selain itu dimaksudkan pula untuk mengembangkan kemampuan menggunakan matematika dalam pemecahan masalah dan mengkomunikasikan ide atau gagasan dengan menggunakan simbol, tabel, diagram, dan media lain.

Pendekatan pemecahan masalah merupakan fokus dalam pembelajaran matematika yang mencakup masalah tertutup dengan solusi tunggal, masalah terbuka dengan solusi tidak tunggal, dan masalah dengan berbagai cara penyelesaian. Untuk meningkatkan kemampuan memecahkan masalah perlu dikembangkan keterampilan memahami masalah, membuat model matematika, menyelesaikan masalah, dan menafsirkan solusinya.

Pembelajaran matematika hendaknya dimulai dengan pengenalan masalah yang sesuai dengan situasi (contextual problem). Dengan mengajukan masalah kontekstual, peserta didik secara bertahap dibimbing untuk menguasai konsep matematika. Untuk meningkatkan keefektifan pembelajaran, sekolah diharapkan menggunakan teknologi informasi dan komunikasi seperti komputer, alat peraga, atau media lainnya.

Melihat hakikat dan karakterisik pembelajaran matematika seperti telah diuraikan diatas, maka para guru perlu mempertimbangkan rancangan tentang keterampilan proses pemecahan masalah matematika, memberikan pengalaman autentik pada siswa, menggunakan model yang dapat meningkatkan keterampilan proses misalnya $P B L$ dan merancang penilaian yang dapat mengukur proses keterangan secara 
autentik misalnya penilaian autentik. Uraian secara medalam atau mendetail tentang keterampilan proses pemecahan masalah matematika, $P B L$ dan penilaian autentik pada bagian tersendiri.

\section{Keterampilan Proses Pemecahan}

\section{Masalah Matematika}

Menurut Wahyudi \& Kriswandani (2010:53) Keterampilan proses merupakan kegiatan belajar mengajar yang berfokus pada penelitian siswa secara aktif dan kreatif dalam proses memperoleh hasil belajar. Hasil belajar yang diperoleh siswa tidak hanya terbatas pada aspek pengetahuan saja melainkan bagaimana proses mencapai tujuan pembelajaran yang diharapkan dapat terpenuhi.

Nyimas Aisyah (2008:5) menyebutkan prinsip-prinsip keteram- pilan proses matematika meliputi: 1) mengamati, yaitu kegiatan yang terarah untuk menangkap gejala atau fenomena sehingga mampu membedakan yang sesuai dan yang tidak sesuai dengan pokok permasalahan menggunakan indera secara optimal dalam rangka memperoleh informasi yang lengkap atau memadai. 2) menghitung, merupakan keterampilan dasar yang digunakan dalam kehidupan sehari-hari. Hasil dari perhitungan dapat disajikan dalam bentuk tabel, grafit dan atau histogram. 3) mengukur, merupakan keterampilan dimana seseorang dapat mengetahui sesuatu yang diamati dengan mengukur apa yang diamatinya. 4) mengklasifikasi, merupakan kemampuan me- ngelompokkan atau menggolongkan sesuatuyang berupa benda, informasi, fakta dan gagasan. 5) memenukan hubungan, merupakan kemampuan menentukan hubungan antara sikap dan tindakan yang sesuai. 6) membuat prediksi, merupakan kemampuan menyusun hipotesis atau suatu perkiraan untuk menerangkan suatu kejadian atau pengamatan tertentu. 7) melaksanakan penelitian, merupakan kegiatan penyelidikan untuk menguji gagasan-gagasan melalui kegiatan eksperimen praktis. 8) mengumpulkan dan menganalisis data, merupakan kemampuan mengenai bagaimana cara-cara mengumpulkan data dalam penelitian baik kuantitatif maupun kualitatif. 9) menginterprestasikan data, merupakan kemampuan untuk menafsirkan data yang telah dikumpulkan dari berbagai kegiaan. 10) mengkomunikasikan hasil, merupakan kegiatan untuk mengkomunikasikan proses dari hasil perolehan kepada berbagai pihak yang berkepentingan, baik dalam bentuk kata-kata, grafik, bagan maupun tabel secara lisan maupun tertulis.

Berdasarkan uraian diatas terlihat bahwa pada prinsipnya pendekatan keterampilan proses pemecahan masalah memberikan kesempatan kepada setiap siswa untuk menemukan dan mengkontruksi sendiri pemahaman ide dan konsep matematika melalui kegiatan pemecahan masalah matematika. Tantangan bagi guru SD dalam 
Peningkatan Keterampilan Proses Pemecahan Masalah Dan Hasil Belajar Matematika Menggunakan Model PBL (Sri Giarti)

mengampu mata pelajaran Matematika adalah seberapa tinggi tingkat pemahaman terhadap hakikat dan karakteristik Matematika, dimensi-dimensi Matematika dan konsisten dalam memilih model pembelajaran yang tepat. Apabila tantangan ini dijawab dengan tepat, maka dimensi-dimensi Matematika, yaitu Keterampilan proses pemecahan masalah matematika, dan hasil belajar siswa dapat ditingkatkan.

\section{Model Pembelajaran Problem Based} Learning (PBL)

Menurut Slameto (2011:7) Model $P B L$ merupakan model pembelajaran model pembelajaran yang melatih dan mengembangkan kemampuan untuk menyelesaikan masalah yang berorientasi pada masalah autentik dari kehidupan aktual siswa, untuk merangsang kemampuan berpikir tingkat tinggi.

Senada dengan Slameto, Hosnan (2014: 295) mengemukakan bahwa Model Problem PBL merupakan model pembelajaran dengan pendekatan pembelajaran siswa pada masalah autentik sehingga siswa dapat menyusun sendiri, menumbuhkan kembangkan keterampilan yang lebih tinggi dan inquiry, memandirikan siswa dan meningkatkan kepercayaan diri sendiri.

Simpulan ini senada dengan ketentuan dalam Kemendikbud (2014), yang menyatakan bahwa Model $P B L$ merupakan sebuah pendekatan pembelajaran yang menyajikan masalah kontekstual sehingga merangsang peserta didik untuk belajar. Model $P B L$ dilakukan dengan pemberian rangsangan berupa masalah-masalah yang kemudian dilakukan pemecahan masalah oleh peserta didik yang diharapkan dapat menambah keterampilan peserta didik dalam pencapaian materi pembelajaran. Lebih lanjut Permendikbud (2014), menjelaskan bahwa langkahlangkah atau sintak model $P B L$ meliputi orientasi permasalahan, pengorganisasian atau perancangan kegiatan penyelidikan, melakukan penyelidikan untuk memecahkan masalah, mempresentasikan hasil penyelidikan, dan mengevaluasi proses pemecahan masalah. Dalam model pembelajaran $P B L$, berawal dari guru mengajukan masalah autentik ataupun mengorientasikan siswa kepada masalah. Selanjutnya, akan memfasilitasi penyelidikan pada saat eksperimen/pengamatan,memfasilitasi dialog antara siswa, juga mendukung proses belajar siswa.

$P B L$ merupakan pembelajaran, penyelidikan autentik, kerja sama dan menghasilkan karya serta peragaan sehingga pembelajaran tidak hanya pada perolehan yang menggunakan masalah autentik yang tidak terstruktur dan bersifat terbuka dalam mengembangkan keterampilan menyelesaikan masalah dan berpikir kritis dan membangun pengetahuan baru. Berkaitan dengan hakikat dan langkahlangkah $P B L$ ini, Aisyah (2011:7) menyebutkan keunggulan model $P B L$ berikut: 1) memungkinkan siswa 
menjadi melek teknologi, melengkapi siswa dengan keterampilan dan rasa percaya diri untuk sukses dalam kompetisi global, dan juga mengajarkan inti kurikulum dengan cara interdisiplin. 2) Meningkatkan kualitas pembelajaran, mengubah pola mengajar dari memberitahu ke melakukan, menyediakan kesempatan bagi siswa untuk belajar sesuai dengan minat dan membuat keputusan sendiri, serta memberi kesempatan bagi siswa untuk berdiskusi tentang bagaimana mereka akan menemukan jawaban pertanyaan atau memecahkan. 3) Menciptakan kondisi siswa menjadi aktif. 4) Menggali kreatifitas siswa dalam memecahkan masalah. Namun demikian, PBL juga memiliki kelemahan, terutama perlu waktu yang lama untuk menyelesaikan satu siklus pembelajaran.

Berdasarkan hakikat Matematika, karakteristik pembelajaran Matematika seperti telah diuraikan di atas, maka model pembelajaran $P B L$ dapat dijadikan salah satu alternatif model pembelajaran Matematika di SD. Implementasi model pembelajaran $P B L$, secara teoretik dapat meningkatkan kompetensi keterampilan proses peme- cahan masalah matematika para siswa yang nantinya akan berdampak pada penguasaan konsep-konsep matematika. Berbagai penelitian tindakan mem- buktikan potensi $P B L$ tersebut secara empirik. Siswantara, Manuaba \& Meter (2013), meneliti tentang penerapan model Problem Based Learning SD Negeri 8 Kesiman menemukan hasil bahwa model Problem Based Learning dapat meningkatkan aktivitas dan hasil belajar IPA. Wulandari, Budi \& Suryandari (2013) melakukan PTK dan menemukan hasil bahwa penerapan Model $P B L$ dapat meningkatkan proses dan hasil belajar IPA siswa kelas V SD Negeri Mudal Purworejo. Apriani, Riska (2013) melaporkan hasil penelitian berikut: a) penggunaan Model Problem Based Learning dapat meningkatkan performansi guru, b) aktivitas siswa kelas IV SD Negeri Randugunting 3 Kota Tegal. dan hasil belajar siswa pada mata pelajaran IPA. Lohman \& Finkelstein (2002) melakukan penelitian dengan judul Designing Cased in Problem Learning to Foster ProblemSolving Skill melaporkan bahwa model Problem Based Learning dapat meningkatkan keterampilan pemecahan masalah.

Uraian tentang hakikat $P B L$ dan temuan berbagai penelitian tersebut di atas berimplikasi pada desain pembelajaran dan penilaian pembelajaran. Para guru perlu melakukan perancangan pembelajaran dan penilaian dengan baik. Penilaian tidak hanya cukup dengan tes melainkan melalui penilaian autentik yang mencangkup ranah sikap, keterampilan dan pengetahuan. Uraian tentang Penilaian autentik dalam pembelajaran martematika akan dibahas pada bagian selanjutnya. 
Peningkatan Keterampilan Proses Pemecahan Masalah Dan Hasil Belajar Matematika Menggunakan Model PBL (Sri Giarti)

Tujuan dari Model Problem Based Learning (PBL) untuk membantu siswa memperoleh pengalaman dan mengubah pengetahuan, keterampilan, dan nilai atau norma sebagai pengendali sikap dan prilaku siswa.

Mencermati uraian tentang keterampilan proses pemecahan masa- lah, sintak $P B L$ dan potensi $P B L$ seperti di atas, sebenarnya dapat disepadankan dengan keterampilan proses ilmiah dalam pendekatan saintifik. Langkah orientasi permasalahan dilakukan dengan cara mengamati permasalahan dalam pembelajaran matematika. Kegiatan menanya sejalan dengan aktivitas pengorganisasian atau perancangan kegiatan penyelidikan dengan merumuskan permasalahan penelitian. Kegiatan pembelajaran dengan melakukan penyelidikan untuk memecahkan masalah dalam sintak $P B L$ relevan dengan mengumpulkan informasi dan mengasosiasikan. Kegiatan mempresentasikan hasil penyelidikan dan mengevaluasi proses pemecahan masalah merupakan kegiatan yang relevan dengan kegiatan mengkomunikasikan dalam pendekatan saintifik.

Kesepadanan sintak $P B L$ dengan keterampilan proses ilmiah dalam pendekatan saintifik nampaknya juga relevan dengan keterampilan proses pemecahan masalah dalam pembelajaran matematika. Kegiatan mengamati dalam proses keterampilan pemecahan masalah matematika sejalan dengan proses mengamati dalam pen- dekatan saintifik dan kegiatan orientasi permasalahan dalam $P B L$. Kegiatan pengorganisasian atau perancangan kegiatan penyelidikan dalam sintak $P B L$ merupakan kegiatan yang relevan dengan kegiatan menghitung, mengukur, mengklasifikasi, menemukan hubungan, dan memprediksi. Kegiatan melakukan penyelidikan dalam langkah $P B L$ berhubungan dengan kegiatan melaksanakan penelitian serta mengumpulkan, menganalisis dan menginterpretasikan data dalam keterampilan proses pemecahan masalah matematika. Aktivitas mempresentasikan dan mengevaluasi hasil penyelidikan sejalan dengan kegiatan mengkomunikasikan dalam keterampilan proses pemecahan masalah matematika.

Dalam penelitian PTK ini lima pembelajaran didesain berdasarkan sintak dari PBL dan komponen-komponen keterampilan proses pemecahan masalah matematika menjadi obyek amatan dalam proses pembelajaran.

\section{Penilaian Autentik}

Menurut Endang Poerwanti (2008:3) Penilaian autentik atau penilaian alternatif merupakan upaya memperbaiki dan melengkapi tes, sehingga penilaian hasil belajar tidak hanya berhubungan dengan hasil akhir tetapi merupakan bagian penting dalam proses pembelajaran.

Berbeda dengan definisi Endang Poerwanti, Hosnan (2014:387) mendefinisikan penilaian autentik sebagai 
pengukuran yang bermakna secara signifikan atas hasil belajar peserta didik untuk ranah sikap, keterampilan, dan pengetahuan.

Dari definisi penilaian autentik yang dikemukakan oleh Endang Poerwanti (2008:3) dan Hosnan (2014: 387) tersebut di atas, ada benang merah tentang definisi penilaian autentik yaitu pengukuran hasil belajar siswa menggambarkan peningkatan hasil belajar peserta didik, baik dalam rangka mengobservasi, menalar, men- coba, membangun jejaring, dan lain- lain.

Menurut Muslich (2009:47) menyebutkan bahwa penilaian autentik merupakan proses pengumpulan berbagai data yang bisa memberikan gambaran atau informasi tenang perkembangan pengalaman belajar siswa. Gambaran pengalaman belajar siswa perlu diketahui oleh guru agar siswa mengalami proses belajar yang benar.

Hosnan (2014:396) mengungkapkan bahwa teknik penilaian autentik terdiri dari tiga aspek penilaian yaitu: 1) penilaian sikap, penilaian yang dilaku- kan menggunakan lembar observasi kinerja saat siswa bekerja kelompok, bekerja individu, berdiskusi maupun saat presentasi menggunakan. 2) penilaian pengetahuan, penilaian yang dilakukan menggunakan instrumen tes tertulis, instrumen tes lisan dan instrumen penugasan. 3) penilaian proses atau keterampilan, yaitu penilaian yang dilakukan menggunakan penilaian kinerja melalui tes praktik, projek, dan penilaian portofolio.

Simpulan ini senada dengan ketentuan dalam lampiran Permendiknas No 81a Tahun 2013, yang menyatakan bahwa penilaian autentik merupakan penilaian dan pembelajaran secara terpadu. Penilaian autentik harus mencerminkan masalah dunia nyata, bukan dunia sekolah. Menggunakan berbagai cara dan kriteria holistik (kompetensi utuh merefleksikan pengetahuan, keterampilan, dan sikap). Penilaian autentik tidak hanya mengukur apa yang diketahui oleh peserta didik, tetapi lebih menekankan mengukur apa yang dapat dilakukan oleh peserta didik (Permendiknas, 2013:56).

Berpijak pada permasalahan kesenjangan proses dan hasil pembelajaran matematika dan potensi $P B L$ serta keterampilan proses pemecahan masalah matematika seperti telah diuraikan di atas, maka kerangka pikir PTK ini dapat dirumuskan seperti dalam uraian berikut. Temuan awal tentang kondisi pembelajaran Matematika kelas VI di SD $\mathrm{N}$ Bengle 2 Wonosegoro - Boyolali menunjukkan bahwa para siswa kurang memiliki keterampilan proses pemecahan masalah Matematika dan berdampak pada hasil belajar yang belum maksimal. Di sisi lain model pembelajaran yang digunakan guru belum menggunakan model pembelajaran yang sesuai dengan karakteristik Matematika. Oleh karena itu permasalahan ini akan 
Peningkatan Keterampilan Proses Pemecahan Masalah Dan Hasil Belajar Matematika Menggunakan Model PBL (Sri Giarti)

diatasi dengan menggunakan model Problem Based Learning dan penilaian autentik.

Langkah-langkah pembelajaran pada kegiatan awal, kegiatan inti dan kegiatan akhir pembelajaran dirancang sesuai dengan langkah-langkah model pembelajaran PBL. Pada kegiatan ini, para siswa diajak untuk melakukan kegiatan: 1) mengorientasi peserta didik terhadap masalah yaitu memprediksi dan mengajukan hipotesis berdasarkan perkiraan atas kecenderungan atau pola hubungan antar data atau informasi tentang Kompetensi Dasar menyelesaikan masalah yang berkaitan dengan satuan debit. 2) Kemudian para siswa diajak mengorganisasikan masalah dengan mencari alternatif strategi untuk menyelesaikan masalah mengenaisatuan debit. 3) Selanjutnya siswa melakukan percobaan secara kelompok untuk mengumpulkan data atau informasi. Kegiatan berikutnya 4) mengembangkan dan menyajikan hasil karya, yaitu mengkomuni- kasikan secara tertulis laporan dari proses merumuskan hipotesis sampai dengan menyimpulkan hasilnya. 5) Kemudian kegiatan terakhir, siswa diminta menganalisis dan mengevaluasi proses pemecahan masalah yaitu guru dan siswa mengevaluasi dan mengevaluasi proses pemecahan masalah yang dipresentasikan setiap kelompok.

Dengan langkah-langkah pembelajaran seperti diuraikan dalam kerang- ka pikir di atas, tujuan dari model pembelajaran PBL akan tercapai. Tujuan tersebut adalah meningkatnya kompetensi keterampilan proses pemecahan masalah maematika dan peningkatan penguasaan konsepkonsep hasil belajar Matematika.

\section{METODE PENELITIAN}

Penelitian tindakan kelas (PTK) ini dilakukan di SD Negeri 2 Bengle, Kecamatan Wonosegoro - Boyolali pada mata pelajaran Matematika kelas VI Semester 1 Tahun Pelajaran 2014/ 2015. Pelaksanaan penelitian tindakan kelas ini dilakukan melalui tahapan penyusunan proposal penelitian, penyusunan instrument, pelaksanaan tindakan dalam rangka pengumpulan data, analisis data dan pembahasan hasil penelitian serta penyusunan laporan PTK. Waktu pelaksanaan setiap tahap PTK adalah sebagai berikut: 1) penyusunan proposal penelitian dilakukan pada Juni tahun 2014; 2) Penyusunan instrumen PTK dilakukan pada Agustus minggu ke -3 tahun 2014; 3) Pelaksanaan tindakan siklus 1 dilakukan pada Agustus minggu ke-4 tahun 2014. Siklus 2 dilakukan pada September minggu ke-1 tahun 2014. Penentuan tindakan ini karena pertimbangan urutan pokok bahasan pada kelas VI dan kalender pendidikan di SDN 2 Bengle.

Subyek yang dilibatkan dalam penelitian tindakan kelas ini adalah siswa kelas VI yang berjumlah 13 yaitu 7 laki-laki dan 6 perempuan. 
Sumber data primer berasal dari hasil pengukuran variabel penelitian tindakan kelas berikut: 1) skor hasil belajar siswa sebagai cerminan dari penguasaan konsep matematika, 2) skor tingkat keterampilan proses pemecahan masalah. Sumber data sekunder berasal dari hasil pengamatan teman sejawat terhadap aktivitas pembelajaran, yang terdiri dari: 1) tingkat aktivitas guru dan 2) tingkat aktivitas siswa dalam pembelajaran.

Teknik pengumpulan data dalam penelitian ini menggunakan teknik tes dan non tes. Instrumen non tes berupa: 1) instrumen pengumpulan data hasil belajar Matematika meng- gunakan test hasil belajar, 2) instrumen pengumpulan data mengenai keterampilan proses pemecahan masalah menggunakan rubik keterampilan proses pemecahan masalah. Kisi-kisi instrumen pengukuran keterampilan proses pemecahan masalah mencakup mencakup 10 item dari 10 komponen, yaitu komponen keterampilan mengamati (item no. 5), mengihitung (item no. 3), mengukur (no. 7), mengklasifikasi (item no. 1), menemukan hubungan (no. 9), membuat prediksi (item no. 6), melaksanakan penelitian (item no 10.), mengumpulkan dan menganalisa data (item no. 4), menginterpretasikan data (item no. 2), mengkomunikasikan hasil (item no. 8). Kisi-kisi instrumen pengukuran hasil belajar Matematika mencakup 10 item soal, terdiri dari: menjelaskan pengertian debit (item no. 1), melakukan percobaan untuk menemukan rumus debit, volume dan waktu (item no. 3, 5, dan 8) menghitung besar debit (item no. 2, 4, 6,7, 9, dan 10).

Analisis data yang digunakan adalah teknik analisis deskriptif komparatif. Data kuantitatif yang diperoleh di deskripsikan dalam bentuk kata-kata atau penjelasan. Baik data yang diperoleh dari hasil tes siswa. Rubik keterampilan proses siswa. Selanjutkan dilakukan komparasi data setiap siklus untuk memastikan ada tidaknya peningkatan hasil belajar siswa, peningkatan keterampilan proses pemecahan masalah matematika. Sebagai tolok ukur keberhasilan pelaksanaan penelitian tindakan kelas ini ditetapkan indikator kinerja sebagi berikut: 1) Persentase jumlah siswa yang mencapai KKM sebesar 50\% untuk siklus 1, dan siklus 2 sebesar $75 \%$;2) meningkatnya keterampilan proses sains minimal sebesar $20 \%$ untuk setiap siklus.

Prosedur PTK ini terdiri dari empat tahapan yang saling terkait dan berkesinambungan, yaitu perencanaan (planning), tindakan (action), observasi (observe), serta refleksi (reflect). (Ditjen Dikti, 1999:25).

\section{HASIL DAN PEMBAHASAN Deskripsi Hasil Tiap Siklus dan Antar Siklus}

Setelah melakukan analisa terhadap data yang diperoleh dari dua siklus yang dilaksanakan, maka dapat disim- 
Peningkatan Keterampilan Proses Pemecahan Masalah Dan Hasil Belajar Matematika Menggunakan Model PBL (Sri Giarti)

pulkan bahwa penggunaan model PBL tingkat Keterampilan Proses Pemecamateri Debit air menunjukkan peningkatan Keterampilan proses pemecahan han Masalah dari kondisi awal, siklus 1 masalah dan ketuntasan hasil belajar sampai siklus 2

siswa. Tabel 1 merangkum komparasi

Tabel 1 Komparasi Keterampilan proses pemecahan masalah

\begin{tabular}{|l|c|c|}
\hline \multirow{2}{*}{ Pembelajaran } & \multicolumn{2}{|c|}{$\begin{array}{c}\text { Tingkat Keterampilan Pemecahan Masalah } \\
\text { Matematila }\end{array}$} \\
\cline { 2 - 3 } & Mean & \% Kenaikan \\
\hline KondisiAwal & 23,62 & - \\
\hline Siklus 1 & 28,54 & 20,83 \\
\hline Siklus 2 & 35,46 & 23,55 \\
\hline
\end{tabular}

Dari data dalam Tabel 4.9 diatas, diperoleh temuan: a) pada kondisi awal, rata-rata tingkat keterampilan proses pemecahan masalah matematika siswa baru mencapai 23,62 (skor maksimal ideal 40); b) pada siklus 1, rata-rata tingkat keterampilan proses pemecahan masalah matematika siswa mencapai 28,54. Capaian ini menunjukkan peningkatan keterampilan sebesar 20,83\%; c) pada siklus 2 , rata-rata keterampilan proses pemecahan masalah matematika mencapai 35,46 . Data ini menunjukkan peningkatan keterampilan proses sains sebesar $23,55 \%$.
Kenaikan mean hasil belajar dan persentase jumlah ketuntasan belajar siswa dirangkum dalam Gambar 1. Dari Gambar 1 diperoleh data berikut: a) pada kondisi awal, mean hasil belajar baru 40 , sedangkan persentase jumlah siswa yang mencapai KKM hanya $23,07 \%$ (3 siswa); b) pada siklus 1, mean hasil belajar menjadi 62,31 dan persentase meningkat menjadi 53,84\% (7 siswa); c) pada siklus 2, mean hasil belajar meningkat menjadi 75,38 dan persentase jumlah siswa yang mencapai KKM meningkat menjadi $84,61 \%$ (11 siswa)

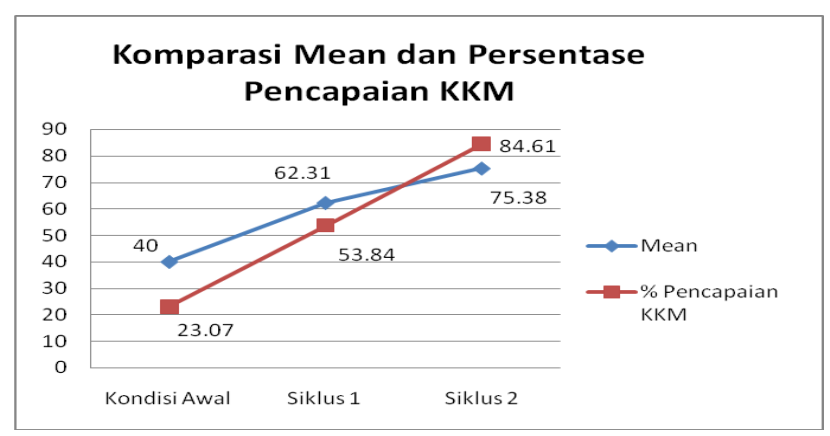

Gambar 1. Komparasi Mean dan Ketuntasan Belajar Siswa 
Temuan Penelitian dan Pembahasan

1. Keberhasilan model PBL dalam meningkatkan keterampilan proses pemecahan masalah matematika

Data pada tabel keterampilan proses pemecahan masalah matematika kondisi awal, siklus 1 dan siklus 2 menunjukkan temuan rerata keterampilan proses pemecahan masalah matematika pada kondisi awal 23,62 pada siklus 1 28,54 dan siklus 2 35.46. Temuan ini mengindikasikan adanya peningkatan tingkat keterampilan proses pemecahan masalah matematika. Besaran peningkatan $20,83 \%$ pada siklus 1 dan $23,556 \%$ pada siklus 2. Jika dibandingkan dengan indikator kinerja 20\% ternyata temuan siklus 1 dan 2 tersebut telah mencapai keberhasilan.

Keberhasilan penelitian ini bermakna bahwa siswa mampu mengamati, mengukur, mengklasifikasi, menemukan hubungan, membuat prediksi, melaksanakan penelitian, mengumpulkan dan menganalisis data, menginterprestasikan data, mengkomunikasikan hasil Temuan ini sejalan dengan penelitian Siswantara, Manuaba \& Meter (2013), Wulandari, Budi \& Suryandari (2013), Apriani, Riska (2013) dan Lohman \& Finkelstein (2002).

2. Keberhasilan model PBL dalam meningkatkan hasil belajar siswa
Data pada grafik 1 hasil belajar siswa kondisi awal, siklus 1 dan siklus 2 menunjukkan temuan kondisi awal, mean 40, pada siklus 1 mean 62,31, pada siklus 2 mean 75,38. Temuan ini mengindikasikan adanya peningkatan hasil belajar siswa. Besaran peningkatan 53,84\% pada siklus 1 dan $84,61 \%$ pada siklus 2. Jika dibandingkan dengan indikator kinerja 50\% untuk siklus 1, 75\% untuk siklus 2 ternyata temu- an siklus 1 dan 2 tersebut telah mencapai keberhasilan.

Hasil Temuan ini sejalan dengan penelitian Siswantara, Manuaba \& Meter (2013), Budi \& Suryandari (2013), Apriani, Riska (2013).

Keampuhan model PBL mampu meningkatkan keterampilan pemecahan masalah matematika dan hasil belajar siswa. Keampuhan ini terbuktinya dalam sintak/langkah pembelajaran, 1) sintak satu memberikan orientasi permasalahan pada siswa terbukti siswa mampu mengamati. 2) sintak kedua Mengorganisir siswa untuk meneliti terbukti siswa mampu mengamati. 3) sintak ketiga melakukan penyelidikan terbukti siswa menghitung, mengukur, mengklasifikasi, menemukan hubungan, memprediksi, melaksanakan penelitian, mengumpulkan dan menganalisis data, menginterpertasikan data. 4) sintak keempat mempresentasikan hasil pemecahan 
Peningkatan Keterampilan Proses Pemecahan Masalah Dan Hasil Belajar Matematika Menggunakan Model PBL (Sri Giarti)

terbukti siswa mampu mengkomunikasikan hasil. 5) sintak kelima mengevaluasi proses pemecahan masalah terbukti siswa mampu mengkomunikasikan hasil.

Temuan ini sejalan dengan penelitian Siswantara, Manuaba \& Meter (2013), Wulandari, Budi \& Suryandari (2013), Apriani, Riska (2013) dan Lohman \& Finkelstein (2002).

\section{SIMPULAN DAN SARAN \\ Simpulan}

Berdasarkan hasil penelitian dan pembahasan, dapat disimpulkan bahwa Model Pembelajaran PBL dan penilaian autentik dapat:

1. Meningkakan keterampilan proses pemecahan masalah Matematika siswa kelas VI SD Negeri 2 Bengle, Kecamatan Wonosegoro, Kabupaten Boyolali sebesar $28,54 \%$ pada siklus 1 dan pada siklus 2 sebesar $35.46 \%$.
2. Meningkatkan hasil belajar siswa kelas VI SD Negeri 2 Bengle Kecamatan Wonosegoro, Kabupaten Boyolali $53,84 \%$ pada siklus 1 dan pada siklus 2 sebesar $84,61 \%$.

\section{Saran}

Saran yang diajukan dalam penelitian ini adalah, para guru hendaknya: a) menggunakan model pembelajaran $P B L$ dalam pembelajaran matematika, b) melatih siswa untuk berpartisipasi aktif dalam pembelajaran di kelas dan c) mengembangkan keterampilan proses pemecahan masalah matematika.

\section{DAFTAR PUSTAKA}

Aisyah, (2011). Perbedaan Problem Based Learning dan Problem Solving. http://susantojk.blogspot.com/2011/07/problem-based-learning-danproblem.html. Diakses tanggal 11 Agustus 2014.

Apriani Riska (2013). Peningkatan Pembelajaran Perubahan Lingkungan Melaui Model Problem Based Learning pada Siswa Kelas IV Sekolah Dasar Negeri Randugunting 3 Kota Tegal. Skripsi UNNES Semarang Tidak diterbitkan.

Depdiknas. (2006). Lampiran Permendiknas No. 22 Tahun 2006 tentang Standar Isi Kurikulum SD/MI tahun 2006. Jakarta: Depdiknas. 
Heruman. (2007). Model pembelajaran matematika di Sekolah Dasar. Bandung: PT Remaja Rosdakarya

Hosnan. (2014). Pendekatan Saintifik dan Kontekstual Dalam Pembelajaran Abad

21. Bogor: Ghalia Indonesia.

Kemendikbud, (2014). Materi Pelatihan Implementasi Kurikulum 2013. Jakarta:

Badan Pengembangan Sumber Daya Manusia Pendidikan dan Kebudayaan dan Penjaminan Mutu Pendidikan Kementerian Pendidikan dan Kebudayaan.

Lohman \& Finkelstein. (2002). Designing Cased in Problem Learning to Foster Problem-Solving Skill. Research in Dental Education Jurnal, 6 (1):121127.

Muslich, M. (2009). KTSP, Pembelajaran Berbasis Kompetensi dan Kontekstual. Jakarta: Bumi Aksara.

Nyimas Aisyah. (2008). Pengembangan Pembelajaran Matematika SD. Jakarta: Direktorat Jendral Pendidikan Tinggi..

Siswantara, Manuaba \& Meter (2013). Penerapan Model Problem Based Learning (PBL) Untuk Meningkatkan Aktivitas dan Hasil Belajar IPA Siswa Kelas IV SD Negeri 8 Kesiman. Jurnal Garuda Portal,(1):1-10.

Slameto (2011). Sertifikasi Guru Bahan Ajar. Semarang: Universitas Negeri Semarang.

Wahyudi \& Kriswandani. (2010). Pengembangan Pembelajaran Matematika SD. Salatiga: UKSW

Wahyudi. (2012). Matematika realistik dan implementasinya dalam proses pembelajaran matematika. Salatiga: UKSW.

Wulandari, Budi \& Suryandari. (2013). Penerapan Model PBL (Problem Based Learning) Pada Pembelajaran IPA Siswa Kelas V SD. Jurnal Kalam Cendekiawan PGSD Kebumen, (1):13-17. 